\title{
Regional Integration of Agricultural Trade in Southern Africa : Infatuation or Real Need?
}

\author{
Alejandro Nin-Pratt \\ International Food Policy Research Institute, Washington, DC, USA \\ Xinshen Diao \\ International Food Policy Research Institute, Washington, DC, USA
}

\begin{abstract}
The potential benefit of several regional integration initiatives undertook by African countries in recent years is a contentious issue that is continuously being debated. This article assesses the impact of a free trade agreement between member countries of the Southern African Development Community on agriculture. Findings show negative welfare results for regional importers because of the increased imports from inefficient regional producers, who are the major beneficiaries of the agreement. To enhance the benefits gained, the region should implement regional policies beyond trade arrangements, such as those enhancing investment, agricultural productivity, and product diversification.
\end{abstract}

\footnotetext{
* Corresponding Author: Alejandro Nin-Pratt; Environment and Production Technology Division, International Food Policy Research Institute, 2033 K Street, NW Washington D.C. 20006, USA; Tel: +202 8625689, Fax: +202 4674439, Email: a.ninpratt@cgiar.org.

Co-Author: Xinshen Diao; Development Strategy and Governance Division, International Food Policy Research Institute, 2033 K Street, NW Washington D.C. 20006, USA; Tel: +202 8628113, Fax: +202 4674439, Email: x.diao@ cgiar.org.
}

\footnotetext{
Acknowledgements: The authors wish to acknowledge Pius Chilonda, Fred Kalibwani, Isaac Minde, anonymous reviewers and participants of the Southern Africa Regional Conference on Agriculture in Gaborone, Botswana (2008), for providing valuable input into a previous version of this paper. The content of this paper, however, is the sole responsibility of the authors.
} 
JEL Classifications: F15, O13, Q17, Q18

Key words: Free Trade Agreement, Southern Africa, Agriculture

\section{Introduction}

Since the success of export oriented growth strategies followed by Asian countries in the 1970s and 1980s, the prevailing view in multilateral lending agencies in the 1980s and 1990s assumed integration into the global economy was essential to achieve economic growth. However, during the multilateral trade negotiations that delivered the Uruguay Round agreement and created the World Trade Organization (WTO), the world saw a stunning growth of regional trading blocs. According to Krugman (1991), the growing importance of regional agreements raised concerns among some economists that regional agreements would undermine multilateralism with no clear gains to be obtained because of the inherent ambiguity of preferential trading agreements. In his 1995 paper, Bhagwati coins the term infatuation referring to the reasons behind the growth of Regional Trade Agreements (RTAs) and argues that their proliferation is leading to the creation of a spaghetti bowl of tariffs whereby a country subjects the same product to different tariff rates depending on its ostensible origin. For Bhagwati, proliferation of regional trade agreements threatens to reproduce the chaos in the tariff regime that was created in the 1930 s by protectionism and the absence of the Most Favored Nation (MFN) principle in trade policy.

Africa was not an exception to these trends and debates. Starting in the late 1980s, countries that have been implementing inward development strategies and interventionist trade policies since independence, undertook substantial trade policy reforms in line with market liberalization policies and regional integration initiatives. Among these regional schemes, the Southern African Development Coordination Conference (SADCC) was formed in April 1980 to promote cooperation in the area of infrastructure. The Southern African Development Community (SADC), which superseded the SADCC, was created in 1992 as a regional organization between nine member countries with the aim to facilitate flexible coordination on national development plans which have potential regional impact. SADC as of today has 15 member countries: Angola, Botswana, The Democratic Republic of the Congo, 
Lesotho, Madagascar, Malawi, Mauritius, Mozambique, Namibia, Seychelles, South Africa, Swaziland, Tanzania, Zambia, and Zimbabwe.

The new vision of SADC was in essence one of trade liberalization and full economic integration of the Southern Africa region. A series of milestones were defined by the Regional Indicative Strategic Development Plan (RISDP) to be achieved within the context of the SADC Common Agenda: a) Formation of a Free Trade Area (FTA) to support inter-regional trade by 2008; b) Establishment of a Customs Union with common external tariffs for the Free Trade Area by 2010; c) Achieve a Common Market by agreeing common policies on production regulation by 2015; d) Attain Monetary Union through macro-economic convergence by 2016; e) Accepting a Single Currency and becoming an Economic Union by 2018.

The process of regional integration formally started with the adoption of the SADC Protocol on Trade in 1996 which came into force in 2000 and was signed by 12 SADC Member States. Angola, the Democratic Republic of Congo, and Seychelles have asked for more time before joining the FTA. Once the Trade Protocol came into force in 2000, the first major step for Member States was to undertake negotiations for the gradual removal of customs duties. The process of eliminating tariffs was guided by the principle of asymmetry out of the realization that SADC Member States were at varying levels of economic development. Member States were put into three categories: (i) Developed Countries (mainly South Africa but de facto, Southern African Customs Union - SACU); (ii) Developing Countries (Mauritius and Zimbabwe) and; (iii) Least Developed Countries (Angola, the Democratic Republic of Congo, Madagascar, Malawi, Mozambique, Tanzania, and Zambia).

Different product categories were defined for the tariff phase down. Category A products were those whose tariffs would move to $0 \%$ at the start of the phase down process in 2000; Category B products were those subject to tariff phase down to $0 \%$ over an 8-year period to 2008; Category C products were sensitive products, phase down over a 12-year period to 2012; Category E products were those products excluded from preferential trade. Sensitive products under Category C comprise only $2.8 \%$ of all agricultural products, and included products such as textiles, clothing/cotton, cereals, dairy products and motor vehicles. Wheat flour, textiles/garments and sugar were also considered very sensitive and hence were given special treatment under the tariff phase down process. In addition to the removal of tariffs, Member States have also agreed to several other trade facilitation measures such as the elimination of non-tariff barriers to trade that involve harmonization of customs rules and procedures, harmonization 
of sanitary and phytosanitary measures as well as adoption and implementation of common rules of origin.

The Southern African Development Community (SADC) Free Trade Area was achieved in August 2008, when 85\% of intra-regional trade amongst the partner states attained zero duty (Category A and B products), which is the threshold stipulated by the World Trade Organization to achieve FTA status. The tariff phase down process for sensitive products should have been completed by January 2012 but some member states lagged behind in implementing their tariff phase down schedule and in certain cases, the reductions were less than initially scheduled. In this context, the 2010 milestone of achieving the custom union status has not yet been attained and these delays in the implementation of the SADC Customs Union means that the subsequent steps in the chain of integration milestones will also be delayed, including the SADC Common Market and Monetary Union.

The potential benefit of the Regional Trade Agreement (RTA) for SADC countries is a contentious issue that is still being debated. For instance, Cassim (2000), Longo and Sekkat (2001), Subramanian and Tamirisa (2001) have shown that the implementation of an RTA in SADC would have favorable impact on bilateral trade, and that the elimination of agricultural tariffs among SADC countries would benefit real agricultural gross domestic product, and agricultural output in the region. Other expected benefits of RTA are export diversification and the attraction of private investments.

On the other hand, Lewis (2001) and Lewis, Robinson, and Thierfelder (2002) concluded that only limited gains can be achieved through trade expansion given SADC's small size relative to the global economy and the trade imbalances among its members. In this context, Holden (1996) argues that South Africa, the economic powerhouse in the region, has little incentive to seek preferential treatment largely because its share of regional exports remain small relative to its exports to the rest of the world.

Chauvin and Gaulier (2002) established that SADC countries have comparative advantages in similar products and that exports from the region concentrate on a small number of products, more so than in the case of other developing countries. Holden (1996) also finds that regional trading blocs, such as SADC, encourage import substitution industrialization and trade diversion. Other studies by Cassim (2000), Chauvin and Gaulier (2002), Davies (1996), Geda and Kibret (2002), Goldstein (2004),

\footnotetext{
'For 2000 2005, South Africa's agricultural exports to the region were, on average, 20 per cent of its total exports.
} 
Holden (1996), Jenkins, Leape, and Thomas (2000), Longo and Sekkat (2001), Nyirabu (2004) and Radelet (1997) have also argued that an RTA will play a limited role in the region because of the importance of other non-tariffs factors affecting trade like transport and transaction costs, inadequate infrastructure, lack of diversification in sources of comparative advantage, and underdeveloped production structures.

In the case of trade in agricultural products, Koester (1986) found potential opportunities for intra-regional trade in agricultural products, mainly live animals, meat, maize, vegetables, sugar and honey, vegetable oils, and animal feed. Maasdorp (1998) concludes that regional trade can contribute substantially to improved food security, as SADC as a whole has the potential to be self-sufficient in white maize and a wide range of other food crops. It also concludes that there is considerable scope for greater intraregional trade in grain and other food products and for greater cross-border investments in agriculture and agro-industry.

The limited information and analysis about integration in agriculture, as well as the contrasting results among some of the studies reviewed here, justify further exploration of the impact of RTAs on agriculture in SADC. To complement these studies, we combine the use of the most disaggregated bilateral trade data available, four-digit Standard International Trade Classification (SITC) level data, and a methodology that is simple and theoretically sound to assess the potential welfare impacts of an FTA on the agricultural sector of Southern African countries and to determine opportunities and challenges faced by the region as a consequence of such agreement.

Section II present the conceptual framework used for this analysis. Section III presents the methodology used to analyze the contribution of different agricultural industries to changes in the welfare of producers and consumers in different countries, determining the welfare effects of a FTA for different regions and agents. The last section summarizes the findings and discusses policy implications.

\section{Conceptual Framework}

Panagariya (1999, 2000), over the past 20 years, mainly focused on the analysis of static welfare effects of regional integration wave of regionalism. The analysis derives from the Heckscher-Ohlin-Samuelson (HOS) framework of comparative advantage 
and from the theory of customs unions with contributions from the theory of second best that goes back to Viner (1950), Meade (1955), and Kemp and Wan (1976). This literature is concerned with what happens when one or more optimal conditions are not satisfied given that RTAs are essentially discriminatory policies. Under this approach, discussed in Burfisher et al. (2003) and Panagariya (2000), the welfare impacts of RTAs concerning trade creation, trade diversion and terms of trade effects, are determined by a few crucial variables: changes in commodity trade between countries within the RTA; changes in trade between the RTA and the rest of the world; and changes in international prices faced by RTA partners. Three main distinctive methodological approaches can be found in the HOS framework: Revealed Comparative Advantage (RCA) indicators as in Balassa (1965); ex-post econometric evaluations as in Panagariya (2000) and Frankel (1997); and ex-ante counterfactual analysis, based on partial or general equilibrium models as in Deardorff and Stern, (1986), Harris and Cox (1984), and Harrison, Rutherford and Tarr (1994). The study of North American Free Trade Agreement (NAFTA) and the European Community 1992 (EC92) have also shown the range of possible effects that can be captured in such models. A good example of this kind of model is Francois and Shields (1994).

This study employs an ex-ante, partial equilibrium counterfactual analysis of regional trade liberalization in SADC using Grossman and Helpman's (1995) framework and in particular, the adaptation of their framework by Vaillant and Ons (2003). We present this framework for the particular case of a Free Trade Agreement (FTA) and two small economies, $A$ and $B$, which could represent regional import and export markets, respectively. We assume that all goods are produced with constant returns to scale, using labor and a sector specific factor; consumers within each economy have identical preferences which are represented by a quasi-linear utility function. The economy is small and therefore world prices are given exogenously. Without loss of generality, all international prices $\left(P_{i}\right)$ are normalized to one, while domestic prices in countries $A$ and $B$ are equal to the international price increased by an ad valorem tariff. Initially, the MFN principle holds.

To analyze the impact of opening trade of commodity $i$ as part of a FTA between importing country $A$ and exporting country $B$, the key variables are: the value of imports by $A$; supply and exports from $B$; and the import tariffs applied to trade of $i$ in both countries. We assume that country $B$ has a more efficient producer of commodity $i$ than $A$, which means that domestic prices of good $i$ in $A$ and $B$ are: $P_{i}^{A}>P^{B}{ }_{i}$ with $P_{i}^{B}=1$ if $B$ is an efficient exporter of good $i$. 
Figure 1 shows country $A$ 's demand for imports and two different total supply curves for country $B .^{2}$ The location of $B$ 's supply depends on the endowment of the specific factor used by $B$ to produce $i$. If the production capacity of $B$ is small, then total supply of $i$ from country $B$ is represented by $X_{i}^{B 1}$. In this case, total supply from $B$ at price $P_{i}^{A}\left(\left(X_{i}^{B}\left(P_{i}^{A}\right)\right)\right.$ is not enough to satisfy $A$ 's import demand at that price $\left(m_{i}^{A}\left(P_{i}^{A}\right)\right)$. The opposite extreme case is that the specific endowment in $B$ is so large that country $B$ 's supply of $i\left(X_{i}^{B}\left(P_{i}^{B}\right)\right)$ can satisfy $A$ 's import demand at the lower price $P_{i}^{B}$ and still export to the rest of the world. In this case, $B$ 's supply response is represented by the curve $X_{i}^{B 2}$; the price in importer $A$ 's market is now reduced to the price in $B\left(P_{i}^{B}\right)$, total imports in $A$ are $m_{i}^{A}\left(P_{i}^{B}\right)$, and total exports in $B$ are $X_{i}^{B 2}\left(P_{i}^{B}\right)$.

\section{Figure 1. Effects of a Regional Trade Agreement}

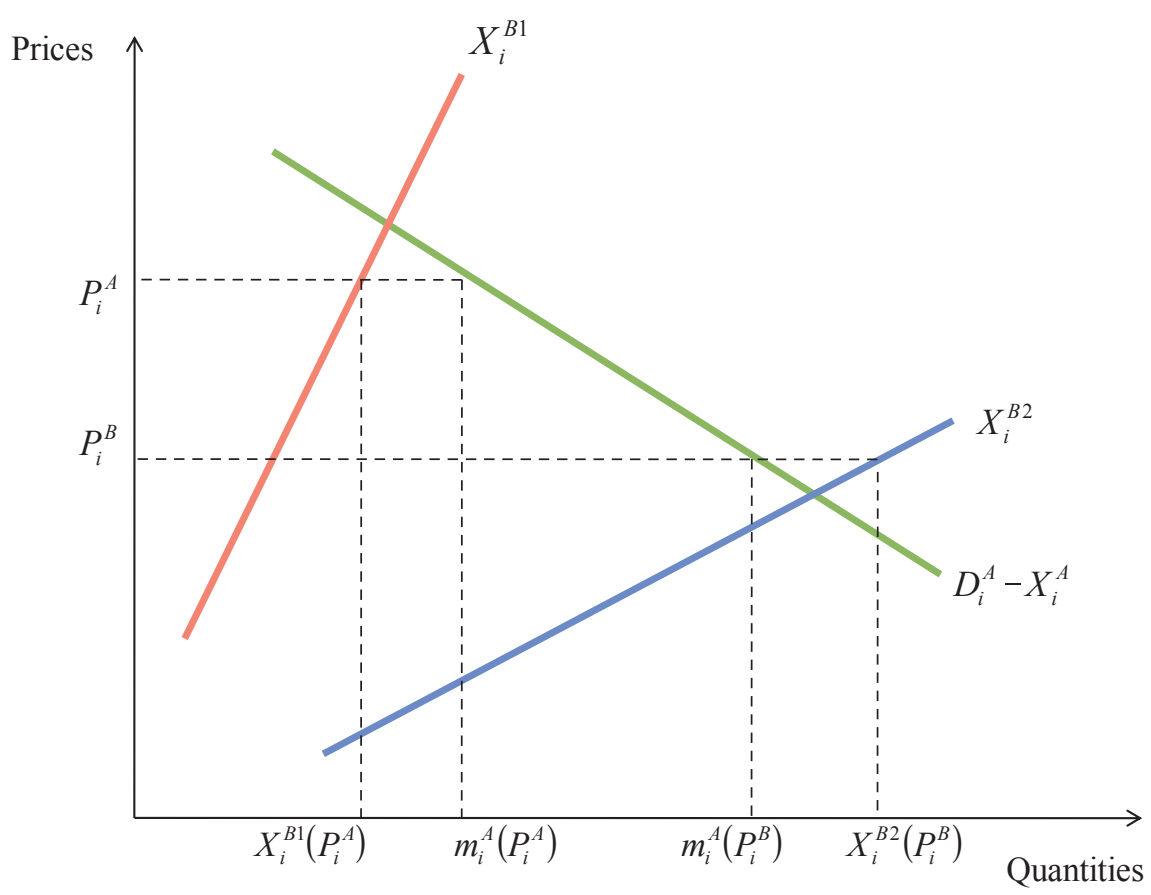

(Source) Adapted from Grossman and Helpman (1995)

Three different outcomes from integration could result in this market depending on the relative size of aggregate supply of $i$ in country $B$ and of import demand of $i$ in

${ }^{2}$ Notice that this is not export supply but total supply of industry $i$ of country $B$. 
country $A$. Grossman and Helpman (1995) refer to these results as: enhanced protection, reduced protection, and the intermediate case. We briefly discuss the first two cases and its implications for each country/region shown by Figure 1. The intermediate case can be seen as a combination of the effects of the two extreme cases and is discussed by Vaillant and Ons (2003).

In the case of reduced protection, supply in country $B\left(X_{i}^{B 2}\right.$ in Figure 1$)$ at the lowest initial price $P_{i}^{B}$ can satisfy all of country $A$ 's import demand, $X_{i}^{B}\left(P_{i}^{B}\right)>m_{i}^{A}\left(P_{i}^{B}\right)$. Under a trade agreement, $A$ stops importing from the rest of the World and its domestic price falls to $P_{i}^{B}$. The producers in $A$ enjoy less protection under the trade agreement than in the initial equilibrium. Producers in $B$ are the only foreign suppliers in $A$ 's market, and they also satisfy at least a part of their domestic market. The price paid by consumers in $B$ for good $i$ and the price obtained by producers in $B$ remains unchanged at the level $P_{i}^{B}$.

A FTA results in enhanced protection for the exporter when supply from country $B$ is small with respect to demand in country $A$ as a result of a relatively small endowment of the specific factor in $B$ (supply $X_{i}^{B 1}$ in Figure 1). At the initial price in $A\left(P_{i}^{A}\right)$, the aggregate supply from country $B$ is not enough to satisfy all the import demand of country $A, X_{i}^{B}\left(P_{i}^{A}\right)<m_{i}^{A}\left(P_{i}^{A}\right)$. Therefore, under an eventual FTA, $A$ has to continue importing from the rest of the world and its domestic price remains unchanged. Given that $P_{i}^{A}>P_{i}^{B}$, producers in $B$ divert all their production to $A$ 's market, while consumers in $B$ have to satisfy all their demand by purchasing from the rest of the world at the initial price. The only effect of the RTA in this case is an increase in those prices paid to producers in the more efficient country. The result is enhanced protection for producers in country $B$.

This classification of industries show that reduced or enhanced protection is directly related to the welfare results of the FTA. When a country applies the same tariff to all nations, it will always import from the most efficient producer with the lowest price. Trade diversion occurs when discriminatory tariff liberalization leads a country to import from a supplier that is not the lowest cost source, thereby reducing the domestic welfare. When increased trade is associated with a switch from higher-cost suppliers to lower-cost suppliers, that is, the supplier in the FTA is more efficient than the supply source before the establishment of the FTA, the FTA is said to be trade creating (Panagariya 2000). ${ }^{3}$ These effects are graphically presented in Figures 2 and 3.

\footnotetext{
3 If FTAs include large countries, then the welfare results depend not only on trade flows and the creation or diversion of trade but also on changes in terms of trade. With imperfect competition, the welfare effects of a FTA may be many times larger than in the case of perfect
} 
Figure 2. Reduced protection as a result of Free Trade Area

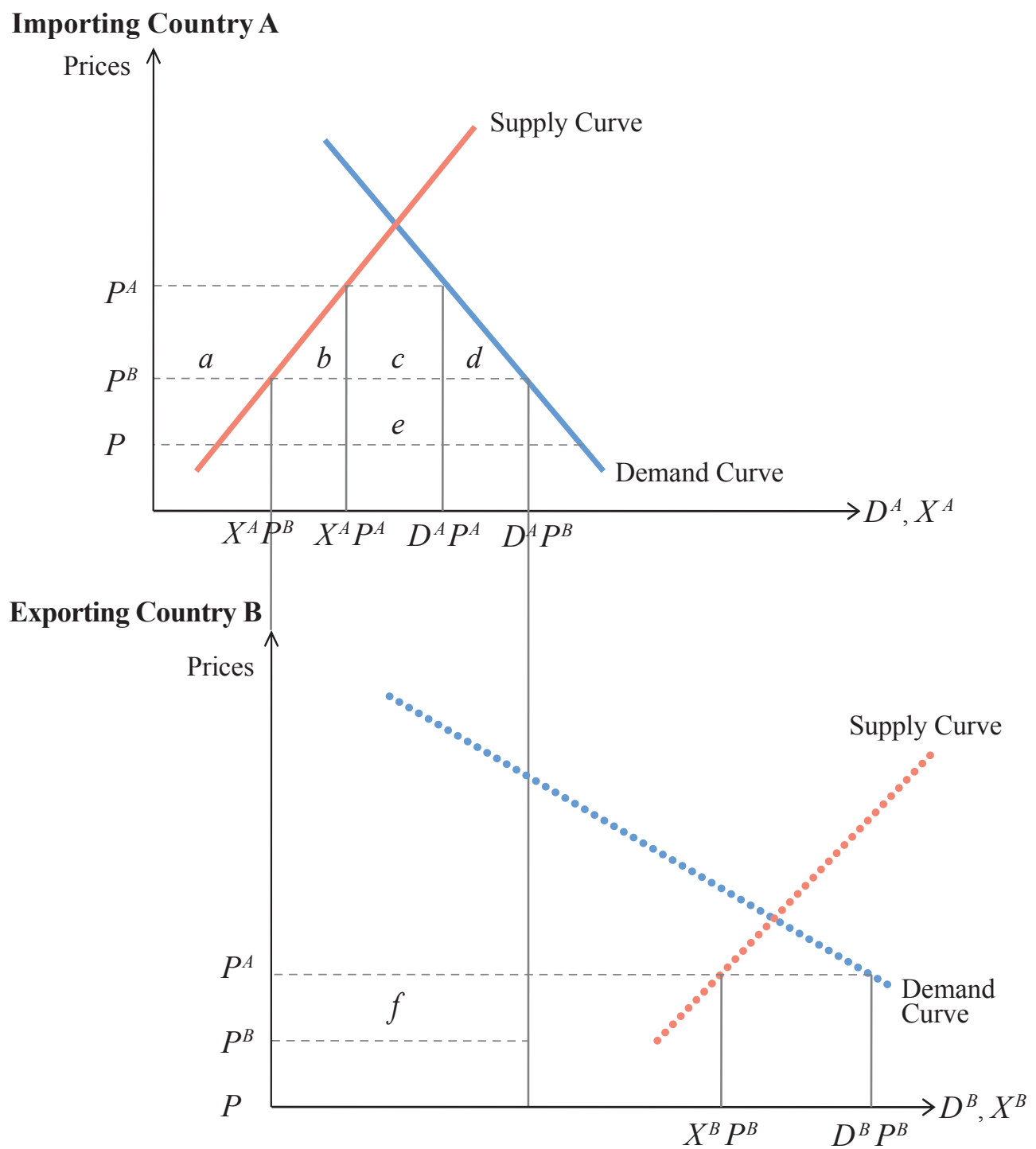

(Source) Vaillant and Ons (2003)

Figure 2 shows welfare changes in an importing country $A$ and an exporting country 
$B$ in the case of reduced protection and an inefficient exporter. It shows that the demand in the importing country is smaller than total supply in the exporting region. When $A$ eliminates tariffs imposed on regional exporter $B$, consumers in $A$ import from $B$ instead of from the rest of the world because now they pay $P_{i}^{B}$ for product $i$ instead of $P_{i}^{A}$ (with $P_{i}^{A}>P_{i}^{B}$ ). With lower domestic prices, producers in $A$ lose area $a$; consumers' surplus increases by area $a+b+c+d$ but area $e$ corresponds to a loss for consumers in tariff revenue given that all imports come from $B$. As production from $B$ is now being exported to $A$, country $B$ imports from the rest of the world at price $P^{B}$ to meet its domestic demand. Consumers in country $B$ gain tariff revenue $f$ as a result of these imports. Given that $f>e$ ( $e$ is only a fraction of $f$ ), the region as a whole gains unambiguously. Exporters in $B$ are not affected by the FTA as they still produce $X^{B}$ at price $P^{B}$. Results in the importing country depend on the relative size of areas $e$ (trade diversion) and $b+d$ (trade creation), which means that if regional exporters in industry $i$ are inefficient, the results for the importing country are ambiguous. When trade creation is bigger than trade diversion, $e<b+d$, then consumers in $A$ benefit from the FTA.

Figure 2 can be also used to show efficient regional exporter. In this case, $P_{i}^{B}=P_{i}$ resulting in $f=e=0$ and areas $b, c$ and $d$ being bigger than in the previous case. Now, consumers in importing country $A$ unambiguously gain, while exporting country $B$ is not affected by the FTA. 


\section{Figure 3. Enhanced Protection as a result of Free Trade Area}

\section{Importing Country A}

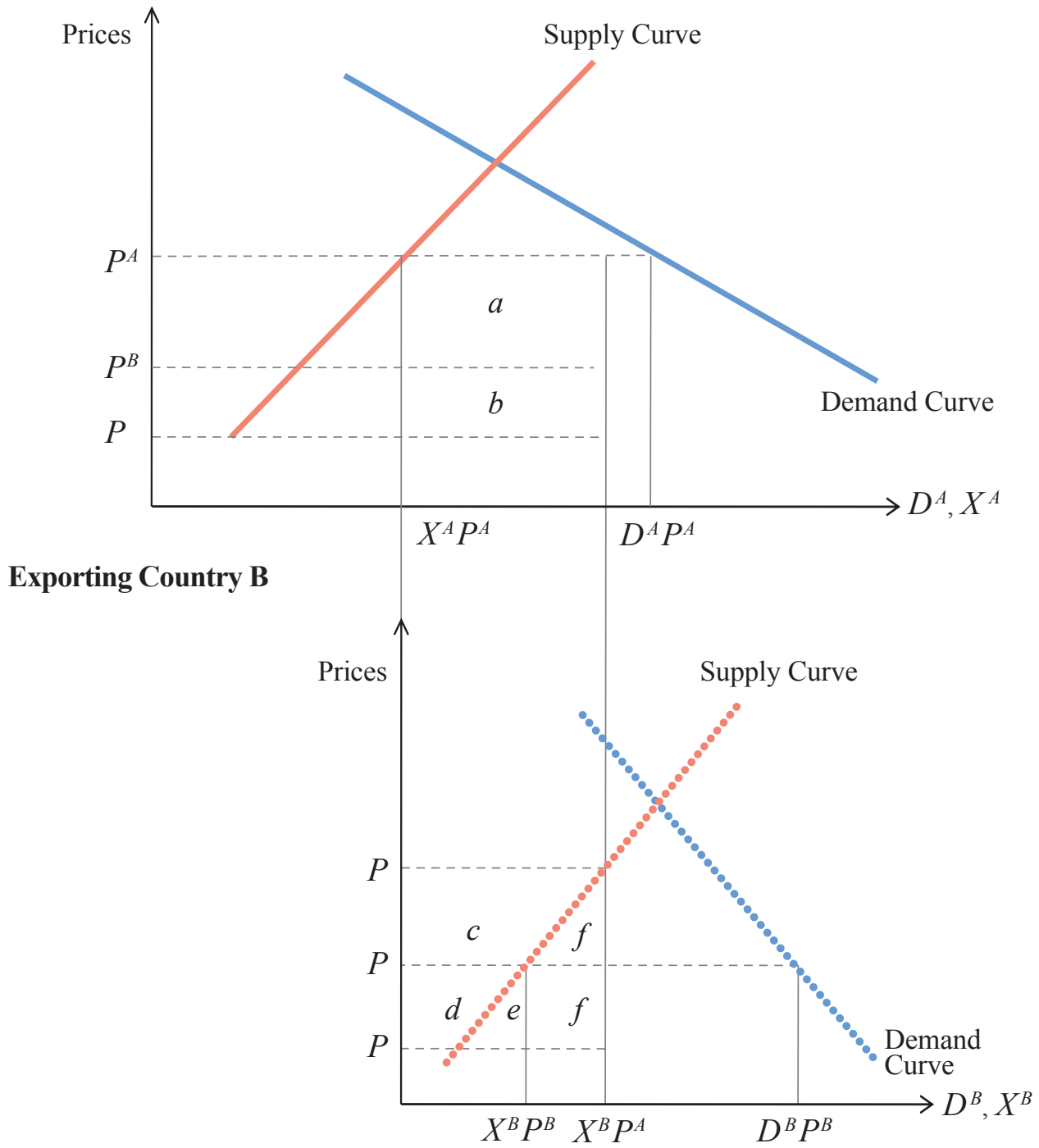

(Source) Vaillant and Ons (2003)

Figure 3 presents the case of enhanced protection with an inefficient regional producer where import demand is larger than total supply in the exporting region. Elimination of tariffs imposed by $A$ result in increased imports from $B$, although in this case, production in $B$ cannot supply total import demand in $A$. As a consequence, $A$ still 
imports from the rest of the world imposing a tariff and because of this, domestic price in $A$ after trade liberalization is still $P_{i}^{A}$. Consumers in country $A$ lose tariff revenue $a+b$ as no tariff is collected from the FTA partner. Exporters in $B$ benefit from their preferential access to country $A$ 's protected market and increase surplus by area $c$, while consumers gain from tariff revenue $d+e$ from increased imports from the rest of the world, as domestic production goes now to country $A$. Total gains in country $B$ result from adding gains in consumer and producer surplus $c+d+e$. As $a+b=c+d+e+f$, net loss for the region is equal to area $f$. The loss in country $A$ does not depend on the level of protection in $B$ but only on the level of its own tariff. All gains in country $B$ now go to producers $(c+d)$ given that there is no tariff revenue for consumers.

In the case of enhanced protection with an efficient producer $\left(P^{B}=P=1\right)$, the loss for the region as a whole is bigger than in the case of the inefficient exporter. The welfare loss in $A$ remains the same and is the result of the loss in tariff revenue. In country $B$ on the other hand, only producers improve their welfare (area $c$ ) but this gain is not sufficient to compensate for the absence of an increment in tariff revenue in $A$.

In sum, assuming that the importer is inefficient and imposes a tariff on imports of product $i$ before the agreement, and depending on: (i) the relative size of import demand in the importing country, (ii) on the total supply in the exporting country, and (iii) on the efficiency of the exporter, we can have the four situations summarized in Table 1. The total effect on the region of the different cases shows that enhanced protection results in unambiguously negative impacts for the region as a whole. On the other hand, reduced protection unambiguously results in trade creation with positive effects on the region as a whole. An intermediate case combining effects of enhanced and reduced protection is possible and is discussed in Vaillant and Ons (2003). 
Table 1. Summary of Regional Welfare effects of a Trade Agreement

\begin{tabular}{|c|c|c|c|c|}
\hline Country & Consumers & Producers & Members & Region \\
\hline \multicolumn{5}{|c|}{ Reduced protection, B inefficient } \\
\hline A (importer) & Ambiguous & Negative & Ambiguous & \multirow{2}{*}{ Positive } \\
\hline B (exporter) & Positive & Nil & Positive & \\
\hline \multicolumn{5}{|c|}{ Reduced protection, B efficient } \\
\hline A (importer) & Positive & Negative & Positive & \multirow{2}{*}{ Positive } \\
\hline B (exporter) & Nil & Nil & Nil & \\
\hline \multicolumn{5}{|c|}{ Enhanced protection, B inefficient } \\
\hline A (importer) & Negative & Nil & Negative & \multirow{2}{*}{ Negative } \\
\hline B (exporter) & Positive & Positive & Positive & \\
\hline \multicolumn{5}{|c|}{ Enhanced protection, B efficient } \\
\hline A (importer) & Negative & Nil & Negative & \multirow{2}{*}{ Negative } \\
\hline B (exporter) & Nil & Positive & Positive & \\
\hline
\end{tabular}

(Source) Adapted from Vaillant and Ons (2003)

Industry $i$ in country $A$ is threatened by the FTA when there is a displacement of domestic production in $A$ led by imports from country $B$ (reduced protection). Exporter $B$ has a trade opportunity when as a result of the FTA, there is an expansion of its production driven by exports to country $A$ (enhanced protection).

We apply this framework to the analysis of a FTA in Southern Africa to determine the welfare effects of the trade agreement on consumers and producers in different countries, on importing and exporting countries, and on the region as a whole. As results in Section IV show, most import markets in Southern Africa appear to be small compared to supply from the region. This means that sensitive industries in most countries are threatened by the FTA and that with the reduced protection under regional trade liberalization, importing countries would reduce domestic production of these industries. 


\section{Approach}

The analysis of the impact of a FTA in Southern Africa using the framework presented in Section II is conducted by following three steps. In the first step, we estimate indices of Revealed Comparative Advantage (RCA) and Revealed Comparative Disadvantage (RCD) for each country and determine the set of industries showing complementarity. The RCA measure proposed by Balassa (1965) implies that a country's pattern of comparative advantage could be observed from post-trade data, assuming that actual trade reflects relative costs as well as differences in nonprice factors, and is grounded in conventional trade theory. As the focus is on trade between SADC countries, the reference used to determine comparative advantage and disadvantage is the group of SADC countries, so our measure refers to advantages and disadvantages relative to the region.

Complementary agricultural industries are defined as the set of industries for which one or more countries in SADC show a comparative advantage (RCA $>1)$ and at the same time, at least one country shows a comparative disadvantage $(\mathrm{RCD}>1)$. As discussed in Vaillant and Ons (2003), industries with high complementarity have a better chance of exploiting the eventual improvement in access to the new partner's market, and we expect that industries within this group will experience the greatest adjustments.

In the second step, we identify the group of sensitive industries. As in Vaillant and Ons (2003), we consider sensitive industries to be those industries showing trade complementarity for which the exporting country in the region faces an ad valorem tariff in regional markets. Thus, sensitive products are those that show trade complementarity between SADC countries and that would gain improved conditions of access to the new partner market as a result of setting up a free trade area. On the other hand, complementary industries are not sensitive if suppliers currently face a zero tariff.

In the last step, we determine which of the sensitive products constitute trade opportunities and perils for the different SADC countries. We focus particularly, on the opportunities and threats that low-income countries face in contrast with those faced by middle-income countries. To do this, we refer to our conceptual framework where industries with reduced or enhanced protection and intermediate industries are defined based on the relative size of import demand $\left(m_{i}^{A}\left(P_{i}\right)\right)$ and supply of exporting countries $\left(P_{i} X_{i}^{B}\left(P_{i}\right)\right)$. We also use the information on initial value of imports and the 
estimated value of imports at exporter's price, together with information on tariffs and import elasticities to estimate the welfare results of the FTA. We assume that $P$, the world price for imports of products from industry $i$ is $P_{i}=1$, and that prices in exporting region $A$ and importing region $B$ are respectively $P_{i}^{A}=1+t_{i}^{A}$ and $P_{i}^{B}=1+t_{i}^{B}$, where $t_{i}$ is an ad valorem tariff. Value of imports after FTA is then calculated using these prices and import elasticities. All reduced protection industries in all countries can be quantitatively measured with prices by trade data to represent current trade value, information on current supply, the areas under the demand and supply curves in Figure 2.

Trade data used in this study is from UN Comtrade, while data on tariffs from Bouët et al. (2004). Broda and Weinstein (2006) describe in detail the import demand elasticities $\left(\varepsilon_{i}^{A}\right)$ used to calculate imports at exporter's price. They report threedigit elasticities for 73 countries in the world using six-digit Harmonized System (HS) import data (1992 classification system) from the UN Comtrade database from 1994 2003 to estimate these elasticities. Information was available for three SADC countries: Madagascar, Malawi and Mauritius. The information from Madagascar and Malawi was used to define elasticity values for low-income countries and the information from Mauritius was used to define elasticities for middle income countries. Given that import elasticity values could be driving our results, we checked different criteria to define these elasticities and compared results obtained with different elasticity values. We conclude that results appear to be robust and that general conclusions hold within a wide range of elasticity values. The Appendices include results of sensitivity analysis for Mozambique to illustrate the procedure followed.

\section{Results}

Table 2 summarizes the general results of our classification of agricultural industries in those industries showing trade complementarity, sensitive industries, and within this group, those facing reduced and enhanced protection. For each group of industries, Table 2 presents the value of imports and exports for each country, the average tariff imposed by importing countries and the average tariff faced by exporters. The first four rows in Table 2 show the total agricultural imports and exports for the region as a whole and by country. Total imports account for 6.5 billion US dollars and exports 
for 10.0 billion US dollars. SADC countries trade products from a total of 193 fourdigit Standard Internation Trade Classification (SITC) industries. From the total set of importing and exporting industries, we find trade complementarity in 106 industries, representing 40 per cent of total imports and 29 per cent of total exports. The average tariff on imports of complementary industries for the region is 10.7 per cent, while countries exporting these products face an average tariff of 16.2 per cent in regional markets. 

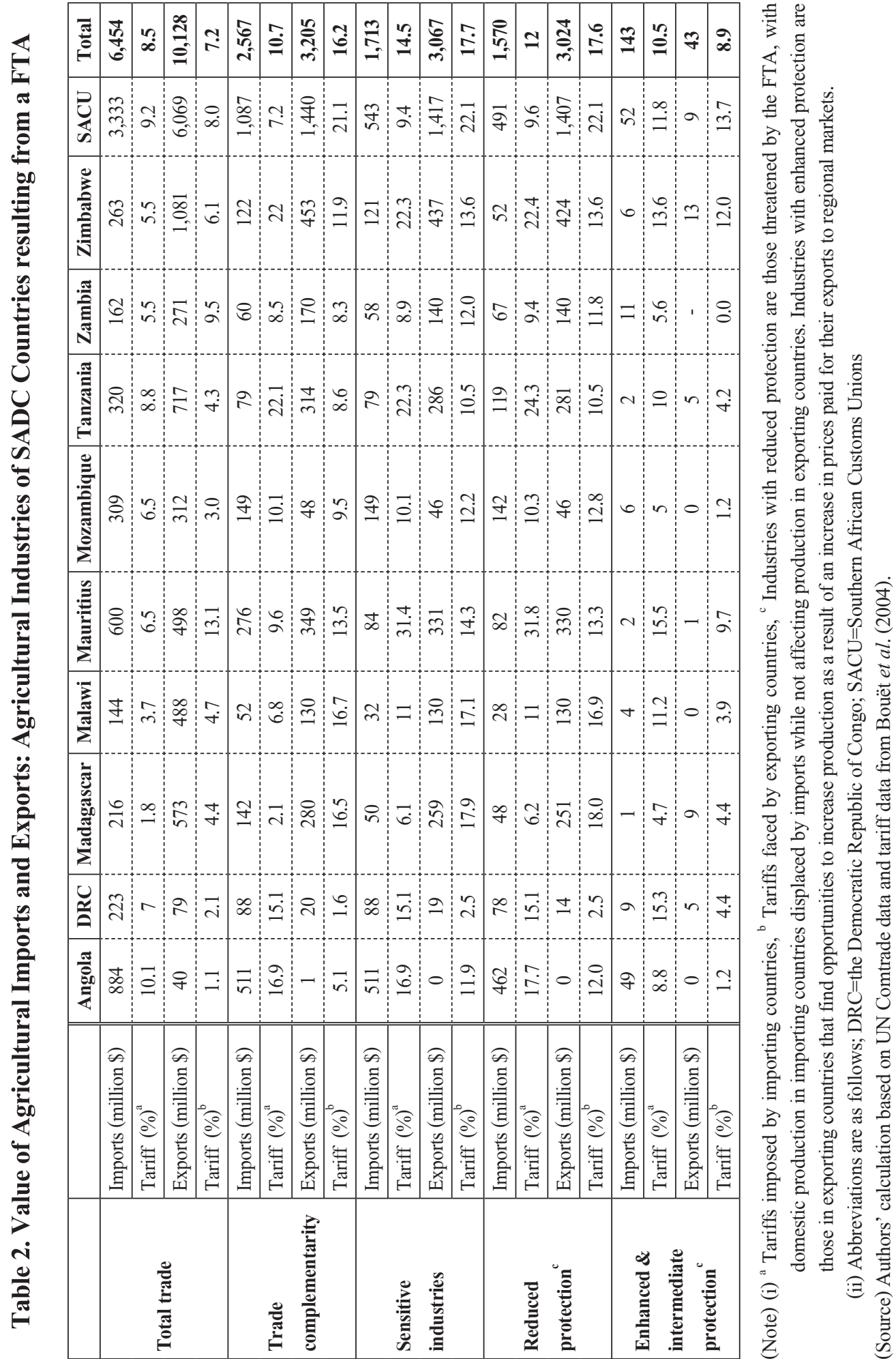
The most important group for analyzing the impact of FTA among SADC countries is the group of sensitive industries. The share of imports and exports of these industries in total regional imports and exports is below 30 per cent, with imports showing an average tariff of 14.5 per cent. Most of the sensitive industries will see reduced protection which means that the effect of a FTA will be to reduce domestic production of these industries in importing countries and increase imports from the region. Opportunities for enhanced protection for exporting countries are small and related to 12 industries with total imports of 143 million US dollars and exports of only 43 million US dollars.

Country level results in Table 2 show that Angola, the Democratic Republic of Congo (DRC), and Mozambique currently appear to have comparative disadvantages for agricultural production in the region. Angola imports 511 million US dollars (58\% of total agricultural imports) of products from 30 industries with high trade complementarity while exporting only 1 million US dollars (2.3 per cent of agricultural exports) from three industries. The DRC also imports more products from industries with trade complementarity than it exports: 88 million US dollars of imports from 20 industries compared with 20 million US dollars of exports from five industries. The value of Mozambique's exports from industries with trade complementarity is only one-third of the value of imports in this group of industries. Southern African Customs Union (SACU) is the major exporter and importer of products from industries with high complementarity in the region, with 1,087 million US dollars imports and 1,440 million US dollars exports. Other net exporters are Madagascar, Mauritius, Tanzania, and Zimbabwe.

As shown in Table 2, producers facing the most significant challenges from SADC's trade agreement are those in the group of industries in countries with reduced protection showing high tariffs, such as Mauritius, Tanzania, and Zimbabwe where the average tariff is greater than 22\% and to a lesser degree, Angola and the DRC where the average tariff is $18 \%$ and $15 \%$, respectively. The agreement will negatively affect producers in 17, 11, and 25 industries in Mauritius, Tanzania, and Zimbabwe, respectively. Angola and the DRC will see protection reduced in more than 20 industries, representing 52 and 35 per cent of total agricultural imports in those countries, respectively. The effect of reduced protection on production will likely be smaller in countries such as Madagascar, Malawi, Zambia, and SACU, where average import tariffs are below 11\% which is low.

According to our results, for producers to benefit from industries with enhanced 
protection under a FTA appears to be very limited and likewise, the negative effect of trade diversion from these industries would also be very limited. Producers who could benefit from enhanced protection are those in the exporting industries in the DRC, Madagascar, SACU, Tanzania, and Zimbabwe. These benefits could be significant for producers in four industries in Zimbabwe, nine in SACU, and five in Madagascar and Tanzania (Table 3). However, the overall effect on agriculture would be small, given that these industries represent 1.2 per cent or less of total exports from these countries.

Table 3. Welfare Gains and Losses for Importing and Exporting from a Free Trade Area

(in millions, US dollors)

\begin{tabular}{|c|c|c|c|c|c|c|c|}
\hline & \multicolumn{3}{|c|}{ Importing industries } & \multirow{2}{*}{$\begin{array}{c}\begin{array}{c}\text { Exporting } \\
\text { industries }\end{array} \\
\begin{array}{c}\text { Trade } \\
\text { creation }\end{array}\end{array}$} & \multirow{2}{*}{$\begin{array}{c}\text { Net welfare } \\
\text { gain }\end{array}$} & \multirow{2}{*}{$\begin{array}{c}\text { Share } \\
\text { of total } \\
\text { gain }\end{array}$} & \multirow{2}{*}{$\begin{array}{c}\text { Share } \\
\text { of total } \\
\text { Agricultural } \\
\text { trade }\end{array}$} \\
\hline & $\begin{array}{c}\text { Trade } \\
\text { creation }\end{array}$ & $\begin{array}{c}\text { Trade } \\
\text { diversion }\end{array}$ & $\begin{array}{l}\text { Net welfare } \\
\text { gain from } \\
\text { imports }\end{array}$ & & & & \\
\hline Low-income & 7,173 & $-16,474$ & $-9,302$ & 96,784 & 87,482 & 68 & 29 \\
\hline Madagascar & 120 & -876 & -756 & 5,191 & 4,436 & 3 & 5 \\
\hline Malawi & 305 & -973 & -668 & 16,182 & 15,514 & 12 & 4 \\
\hline Mozambique & 706 & $-5,134$ & $-4,428$ & 12,135 & 7,706 & 6 & 4 \\
\hline Tanzania & 1,706 & $-4,701$ & $-2,995$ & 18,036 & 15,041 & 12 & 6 \\
\hline Zambia & 584 & $-1,545$ & -961 & 2,078 & 1,117 & 1 & 3 \\
\hline Zimbabwe & 3,751 & $-3,245$ & 506 & 43,162 & 43,668 & 34 & 8 \\
\hline Other & 12,355 & $-31,631$ & $-19,276$ & 60,693 & 41,417 & 32 & 71 \\
\hline Angola & 3,037 & $-16,126$ & $-13,088$ & 4 & $-13,085$ & -10 & 6 \\
\hline DRC & 797 & $-4,594$ & $-3,798$ & 304 & $-3,494$ & -3 & 2 \\
\hline Mauritius & 3,072 & $-9,555$ & $-6,483$ & 22,691 & 16,208 & 13 & 7 \\
\hline SACU & 5,449 & $-1,356$ & 4,093 & 37,694 & 41,787 & 32 & 57 \\
\hline Total & 19,528 & $-48,106$ & $-28,578$ & 157,477 & 128,899 & 100 & 100 \\
\hline
\end{tabular}

(Note) Abbreviations are as follows; DRC=the Democratic Republic of Congo, SACU= Southern African Customs Union

(Source) Authors' calculation 
With respect to the welfare impact of an FTA on agriculture, our analysis indicates that while FTA has a positive welfare impact for the regional economy as a whole, such benefit is small as shown in Table 3. We estimate the total value of trade creation to be 177 million US dollors, or 1.1 per cent of total agricultural trade of SADC countries, while our estimate of the net effect between trade creation and trade diversion is 129 million US dollors, or 0.75 per cent of total agricultural trade. These results indicate that FTA would not have a significant welfare effect on SADC's agriculture.

Main factors explaining this result are the relatively small shares of sensitive industries in total trade that lie below 30 per cent and the low level of tariffs on agricultural products in most countries where the average for sensitive industries are 14.5 per cent. Structural characteristics of SADC countries, like the concentration of agricultural exports among a few commodities and markets, as well as the fact that most SADC countries export a similar group of commodities seems to affect complementarity and constrain the expansion of regional trade and the opportunities of trade creation under a FTA.

At the country level, Table 3 shows that two-thirds of the gains from agricultural trade liberalization would go to low-income countries while almost one-third would go to the Southern African Customs Union (SACU). Countries that benefit the most are those with a comparative advantage for agriculture in the region, while still being inefficient producers of regionally traded commodities like Zimbabwe.

To look at welfare effects at the country level, we divide the effects on welfare gains into two main components: (i) gains for importers as a result of reduced industry protection; and (ii) gains for exporters to markets with reduced protection. We focus on low-income countries and first look at the gains for importers as the result of reduced protection in different markets, as shown in Table 4. Elimination of tariffs in a regional FTA results in negative welfare impacts for importers in all countries except for Zimbabwe, although the absolute values of these losses are small. This means that in industries facing reduced protection, trade diversion dominates trade creation in agriculture when low-income countries open their agricultural markets to the region. This is because the loss in tariff revenue that results from exports from the region is not compensated by the new trade created within the region. As discussed in Section III, trade diversion in the importing country is a result of the importer shifting from an efficient exporter to an inefficient one as a consequence of the FTA. In almost all industries and countries, the welfare effect of a FTA is negative, which is evidence of the importance of inefficient regional exporters. Thus, while we expect a reduction 
of production in several agricultural industries in countries with relatively high tariffs as a result of a FTA, the producer's welfare losses would not be compensated by the consumer's welfare gains. This means that in low-income importing SADC countries, there is no direct gain from opening their agricultural markets to regional imports. 


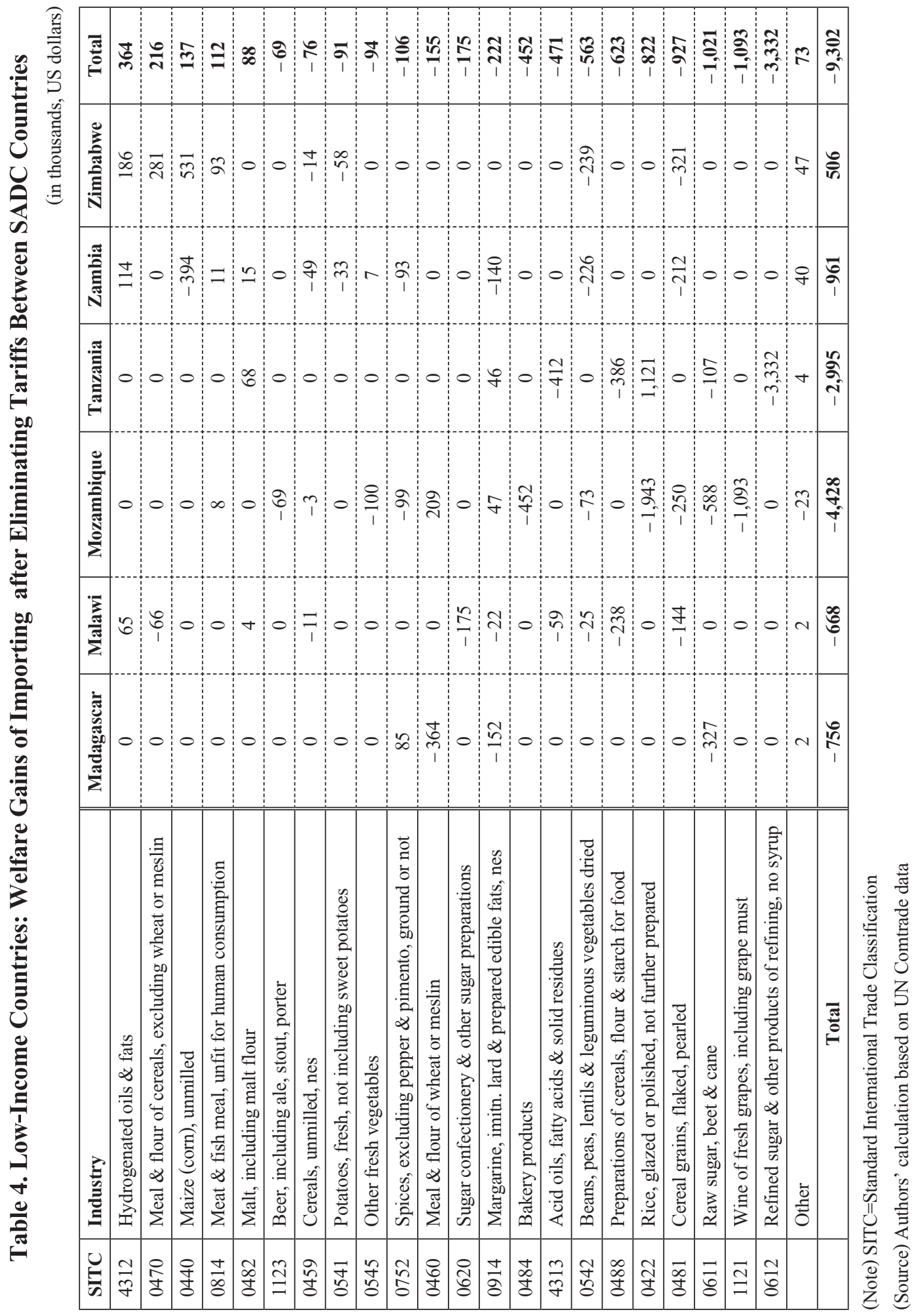


A different picture arises with welfare results of the FTA for countries exporting to markets with reduced protection. Producers in these exporting countries do not benefit from trade because the price they receive is the same as the one they have received before the FTA. However, if the exporter is inefficient with respect to the rest of the world, consumers in exporting countries benefit from the fact that these countries need to import from the rest of the world to compensate for the supply that is now being directed to importing countries in the region. Because the exporting country has a tariff on imports from the rest of the world, imports generate additional tariff revenue, which benefits consumers. This means that the same inefficiency of exporters that results in negative welfare effects for regional importers is the factor explaining welfare gains in exporting countries, with these benefits going to consumers. If the exporter is efficient by imposing no tariffs, then there is no welfare effect, neither positive or negative, for the exporting country as a result of the FTA. Table 5 summarizes welfare results for countries exporting to markets with reduced protection in the region. 


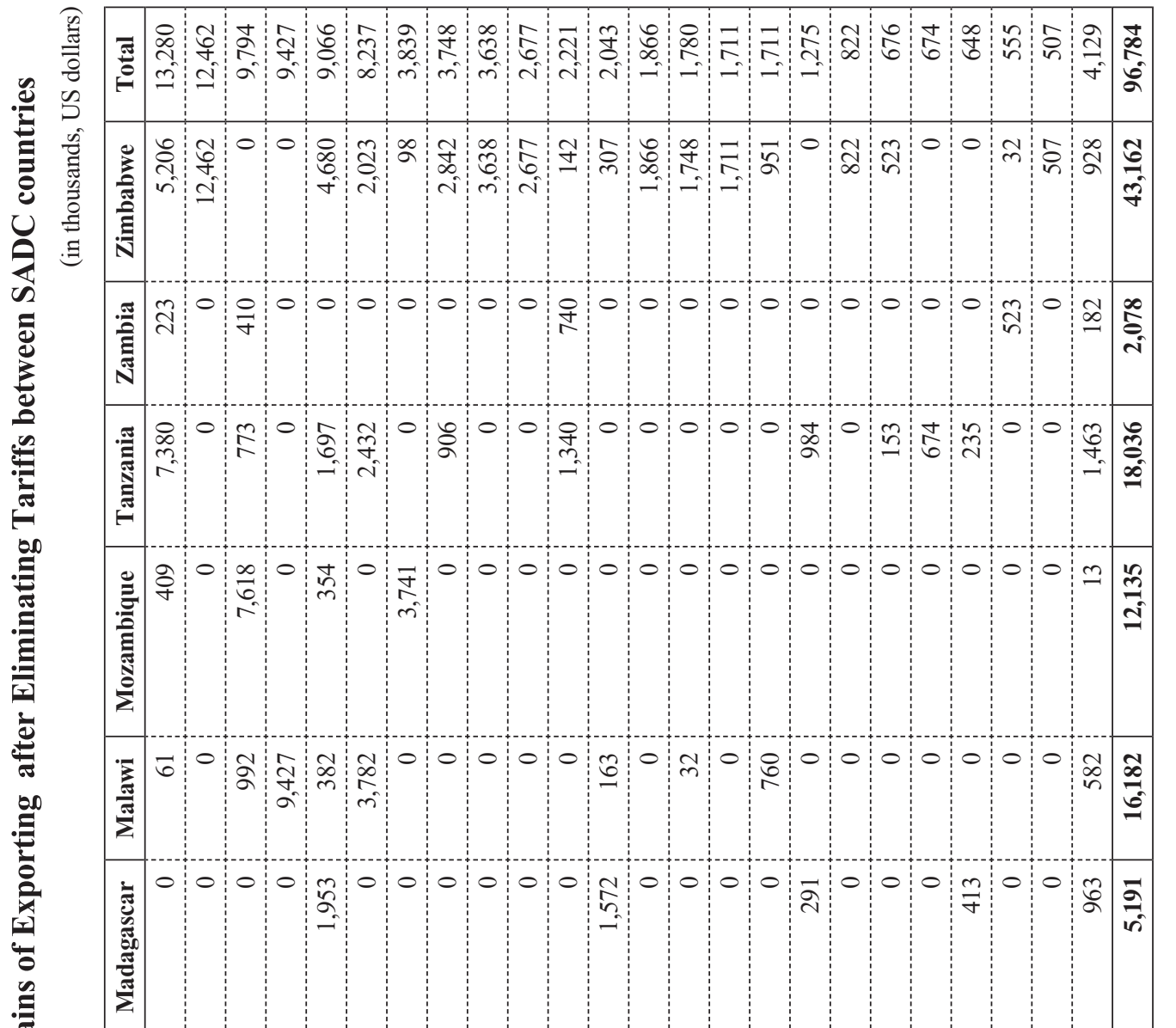


The positive welfare effects for low-income exporters in SADC shown in Table 5 are 10 times bigger than the negative effects of opening their markets to agricultural trade as importers. Trade gains result from exports of cotton, beer, maize, rice, oilseed cakes, and tea. Exports from industries such as meat of swine, cigarettes, leather of other bovine animal, malt, meal and flour of wheat, refined sugar and other products, bakery products, manufactured tobacco, and margarine also contribute to significant welfare gains. Most welfare gains go to regional exporters, many of which are protected from the rest of the world by tariffs. Zimbabwe receives almost half of the total welfare gains of low-income countries. The other half is shared by Malawi, Mozambique, and Tanzania.

Table 6 presents total net welfare gains for low-income countries. This table was obtained by adding welfare results for each industry and country from Tables 4 and 5 . Zimbabwe, as a relatively inefficient exporter of agricultural products to the region, obtains the largest welfare gain among low-income countries through its exports of beer, cotton, oilseed cakes, leather, cigarettes, and malt, among others. Malawi and Tanzania follow Zimbabwe, with Malawi benefiting mainly from regional exports of rice and tea and Tanzania from exports of tea, oilseed cake, and meal and flour of wheat. Major benefits in other countries come from exports of maize and meat of swine (Mozambique), refined sugar (Madagascar), and meal and flour of wheat (Zambia). 


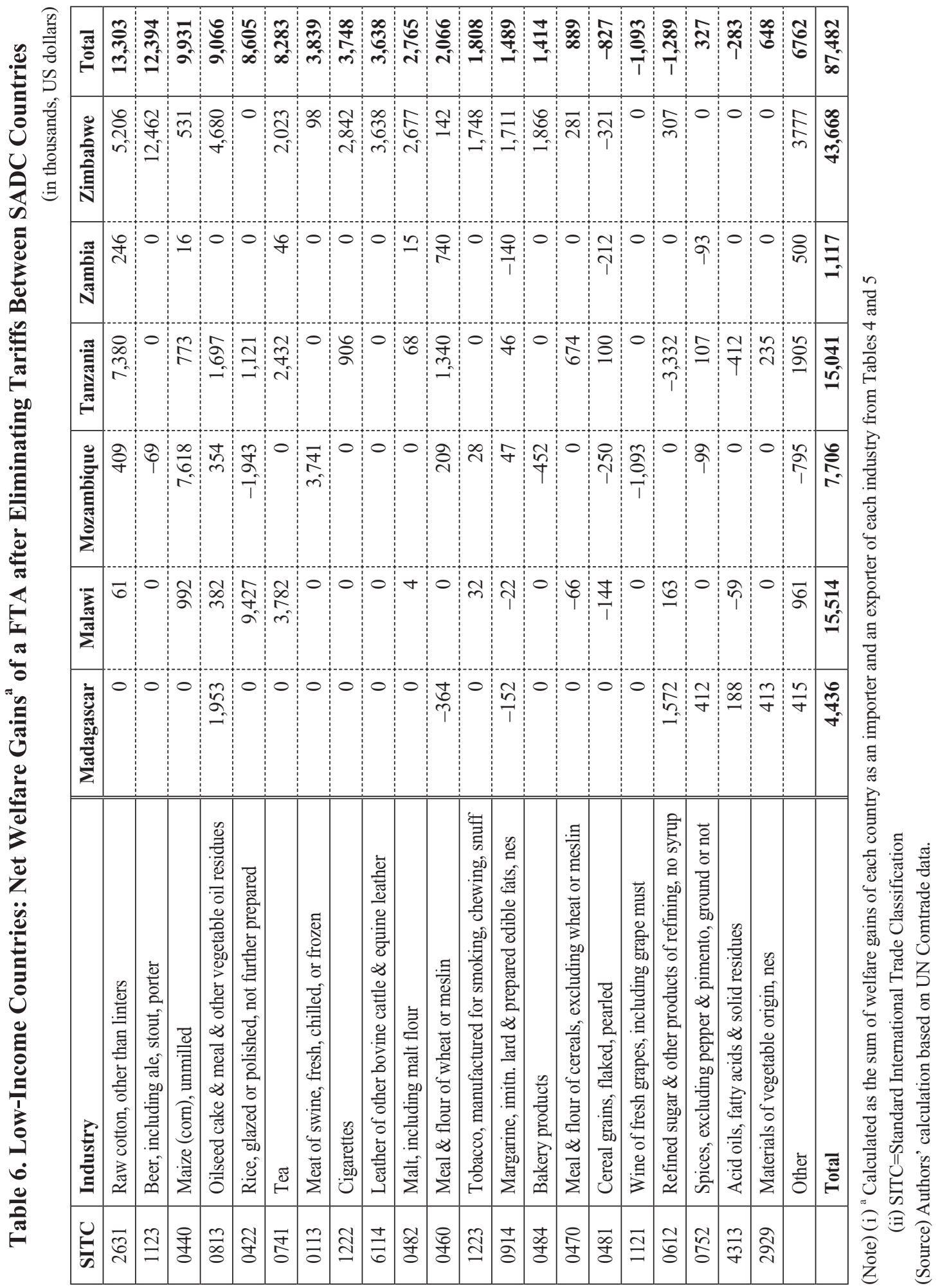


Finally, Table 7 shows net welfare gains for other countries consisting of Angola, the Democratic Republic of Congo, Mauritius, and SACU. Similar to Zimbabwe, SACU benefits from protection from the rest of the world and from its comparative advantage as an agricultural producer in the region. Meal and flour of cereals, wine, beer, and maize explain most of the welfare gains by SACU countries. Mauritius, a country with comparative disadvantage in agriculture with respect to global markets, is able to benefit from a regional FTA with exports of manufactured products from industries like beer and meal and flour of wheat. Angola and the DRC, which have the highest comparative disadvantage for agriculture in the region, lose from the agreement because they import products from protected industries such as wine, beer, meal and flour of wheat, preparation of cereals, sugar, and bakery products. The inefficiency of the main regional exporters also explains the negative welfare impacts of a FTA on regional net importers like Angola and the DRC. This is because the elimination of tariffs on regional imports in these countries would increase imports from inefficient regional producers, with trade diversion dominating trade creation, which offer no direct gain for importing countries in SADC from opening their markets to regional imports. 


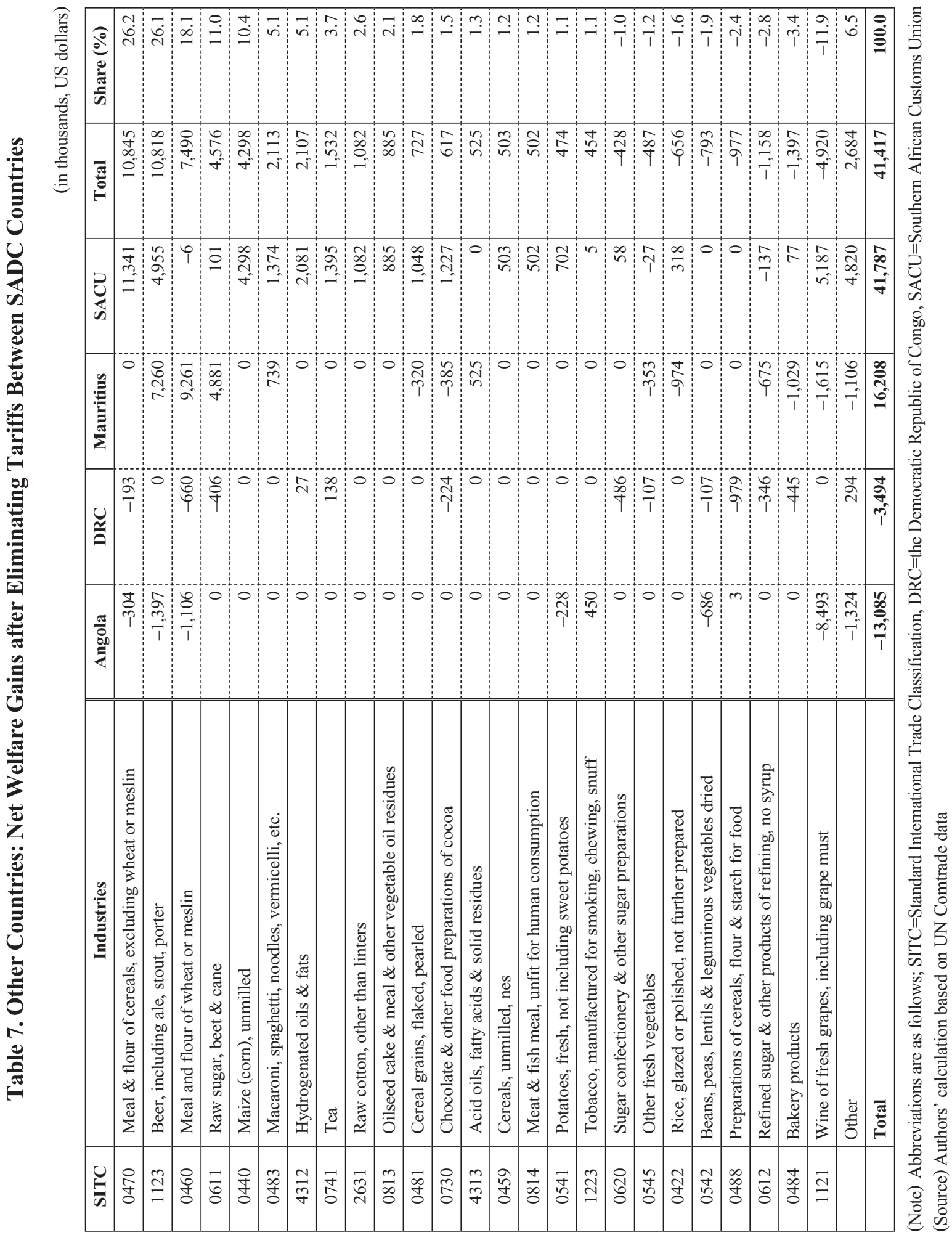


From a political economic perspective and based only on our comparative static results, it could be inferred that FTA offer little incentive to agricultural producers in the region given that no gains are expected for producers in competitive industries, while producers in protected domestic industries are threatened by output reductions and welfare losses. The small size of regional import markets is also a negative factor for producers because it leaves very limited scope for enhanced protection. On the other hand, benefits to consumers in exporting countries appear to be small.

\section{Policy Implications}

In this study, we assess the potential welfare impacts of a Free Trade Area (FTA) on the agricultural sector of Southern African countries and determine opportunities and challenges faced by the region as a consequence of the agreement. We identify agricultural industries that would face challenges under regional liberalization and the impact of the agreement on different countries. To do this, we conduct an ex-ante counterfactual analysis of regional trade liberalization in Southern African Development Community (SADC), using a partial equilibrium approach based on bilateral trade data at the Standard International Trade Classification (SITC) 4-digit level. We found this approach to be best suited for dealing with highly disaggregated trade data.

Our analysis indicates that while a FTA will have a positive welfare impact for the region as a whole, such benefit is small. Countries that benefit the most are those with a comparative advantage for agriculture in the region, while still being inefficient producers of regionally traded commodities. The inefficiency of the main regional exporters also explains the negative welfare impacts of the agreement on net agricultural importers.

At the country level, inefficient agricultural producers with a regional comparative advantage for agriculture will benefit the most from the agreement. Exports from these countries generate trade diversion in importing markets that, in most cases, cannot be compensated for by trade creation from eliminating tariffs. The fact that estimated welfare gains in exporting countries are positive, while they are negative in importing countries shows the importance of regional exports from protected industries in explaining these results. Most benefits to exporting countries come from exports of 
beer, cotton, oilseed cakes, leather, cigarettes, malt, rice, tea, oilseed cake, meal and flour of wheat, and refined sugar.

Looking at the results, agents, consumers, and producers in importing countries lose as a result of trade diversion from regional imports. Producers in exporting countries are not affected, while consumers in exporting countries only benefit when production of exporting industries is protected by tariffs on products from the rest of the world. Consumers in these countries are the ones receiving these benefits, and they result from increased imports from the rest of the world to compensate for the current production being exported to the region, instead of being consumed domestically.

Industries facing output contraction and increased regional imports as a result of the FTA vary from country to country but are mostly concentrated in cereals, cereal preparations, live animals and meat, and industries incorporating higher value added, like beverage and tobacco (wine, beer, cigarettes and manufactured tobacco), spices, fresh and frozen vegetables, raw and refined sugar, animal and vegetable oils, hydrogenated oils and fats, and cotton yarn and thread. In Southern African Customs Union (SACU), the industries that would be the most affected by a regional trade agreement are: non-alcoholic beverages and fermented beverages, dairy (cheese and curd, milk, and cream fresh), tobacco industries (cigarettes, tobacco manufactured), bakery products, natural honey, coffee, tea, cocoa, and spices.

Given regional policy priorities of accelerating growth, increasing income, reducing poverty, and promoting food security in low-income countries, our results suggest that trade policy does not appear to be the most effective means to achieve these goals. This is mainly because of the concentration of agricultural exports among a small number of agricultural industries, the small size of the regional market, and the significant amount of trade diversion that results from the agreement. Export concentration greatly reduces the possibilities of increasing welfare from trade liberalization, reducing trade complementarity. Also, the small size of regional import markets, leaves very limited scope to benefit regional producers through enhanced protection as a result of the FTA. Similarly, no major gains are expected for consumers who could see their welfare negatively affected by increased imports from inefficient regional producers.

These results highlight the importance of reducing tariffs that regional exporters impose to the rest of the world in order to reduce trade diversion and increase benefits for consumers in countries that face output contraction as a consequence of the agreement. Results also suggest that the region should be looking at regional policies beyond trade arrangements, such as those targeting investment, agricultural productivity 
and diversification. With growing productivity and enhanced diversification in agricultural production, regional trade liberalization could play a much more significant role in achieving main policy goals.

Received 2 March 2012, Revised 19 April 2013, Accepted 12 November 2013

\section{References}

Bhagwati, J. (1995), “U.S. Trade Policy: The Infatuation with Free Trade Areas”, Discussion Paper Series No. 726, Columbia University, New York, available at http:// academiccommons.columbia.edu/catalog/ac:100125asof27February2012

Balassa, B. (1965), "Trade liberalization and "revealed" comparative advantage", The Manchester School of Economics and Social Studies, 33, 99-123.

Baldwin, R.E., and Venables, A.J. (1995), "Regional economic integration", in: Handbook of International Economics Edited by Grossman, G., Rogoff. K., North Holland, Amsterdam, p. 1597-1664.

Bouët, A., Decreux, Y., Fontagné, L., Jean, S., Laborde, D. (2004), “A consistent, advalorem equivalent measure of applied protection across the world: The MAcMapHS6 database", Centre d'Etudes Prospectives et d'Informationes Internationales, Paris. Available at: <http://www.cepii.fr/anglaisgraph/workpap/summaries/2004/ wp04-22.htm> as of 11 November 2011, CEPII Working Paper No. 2004-22

Broda, C., Greenfield, J. and Weinstein, D. (2006), "From groundnuts to globalization: A structural estimate of trade and growth", NBER, National Bureau of Economic Research, Cambridge. Working Papers No. 12512,

Burfisher, M.E., Robinson, S. and Thierfelder, K. (2003), "Regionalism: Old and new, theory and practice", "Presented at a conference on Agricultural Policy Reform and the WTO: Where Are We Heading?" Capri, Italy.

Cassim, R. (2000), "The determinants of intra-regional trade in southern Africa with specific reference to South Africa and the rest of the region", Development Policy 
Research Unit, University of Cape Town, Cape Town, Working paper No. 9671,

Chauvin, S., and Gaulier, G. (2002), "Prospects for increasing trade among SADC countries, in: Monitoring Regional Integration in Southern Africa", Editors Hansohm, D., Peters-Berrie, C., Breytenbach, W., Hartzenberg, T., Maier, W., Meyns, P., Gamsberg McMillan, Windhoek, p. 21-42.

Davies, R. (1996), "Promoting regional integration in southern Africa: An analysis of prospects and problems from a South African perspective", African Security Review $5,20-35$.

Deardorff, A.V., and Stern, R.M. (1986), “The Michigan Model of World Production and Trade: theory and applications", MIT Press, Cambridge.

Diao, X., and Robinson, S. (2003), "Market opportunities for southern African agriculture in the new trade agenda: An economy-wide analysis from a global CGE model", International Food Policy Research Institute, Washington, D.C., Unpublished paper.

Francois, J., and Shields, C.R. (1994), "Modelling Trade Policy: Applied General Equilibrium Assessments of North American Free Trade", Cambridge University Press, Cambridge.

Frankel, J.A. (1997), "Regional Trading Blocs in the World Economic System", Institute for International Economics, Washington, DC.

Geda, A. and Kibret, H. (2002), "Regional economic integration in Africa: A review of problems and prospects with a case study of COMESA", Unpublished. Available at http://mercury.soas.ac.uk/economics/workpap/adobe/wp125.pdf as of 27 February 2012

Goldstein, A.( 2004), "Regional Integration, FDI, and Competitiveness in Southern Africa", Organization for Economic Cooperation and Development, Development Centre Studies, Paris.

Grossman, G., and Helpman, E. (1995), "The politics of free trade agreements", American Economic Review, 85, 667-90.

Harris, R., and Cox, D. (1992), "North American free trade and its implications for Canada: Results for a CGE model of North American trade, in: United States 
International Trade Commission", "Economy-Wide Modelling of the Economic Implication of an FTA with Mexico and a NAFTA with Canada and Mexico", USITC Publication 2508. United States International Trade Commission, Washington, DC, pp. 139-165,

Harrison, G., Rutherford, T., Tarr, D. (1994), "Product standards, imperfect competition, and completion of the market in the European Union", World Bank, Washington, DC, Policy Research working paper series 1293.

Holden, M. (1996), "Economic integration and trade liberalization in southern Africa: Is there a role for South Africa?", World Bank, Washington, DC, Discussion paper 342.

Jenkins, C., Leape, J. and Thomas, L. (2000), “Gaining from Trade in Southern Africa: Complementary Policies to Underpin the SADC Free Trade Area", Palgrave, London.

Kemp, M.C., Wan, H. (1976), “An elementary proposition concerning the formation of customs unions", Journal of International Economics 6, 95-8.

Koester, U. (1986), "Regional cooperation to improve food security in southern and eastern African countries. Research Report 53", International Food Policy Research Institute (IFPRI), Washington DC.

Krugman, P. (1991), "The move towards free trade zones", Federal Reserve Bank of Kansas City Economic Review”, November/December, 7-25.

Lewis, J.D. (2001), "Reform and opportunity: the changing role and patterns of trade in South Africa and SADC: A synthesis of World Bank research", World Bank, Washington DC., Africa Region Working Paper Series No. 14.

Lewis J.D., Robinson, S., Thierfelder, K. ( 2001), "Free Trade Agreements and the SADC Economies", Trade and Macroeconomic Division Working Paper No 80, International Food Policy Research Institute (IFPRI), Washington DC.

Longo, R., Sekkat, K. (2001), "New forms of co-operation and integration in emerging Africa: Obstacles to expanding intra-African trade", OECD Development Centre, Organization for Economic Cooperation and Development, Paris, Technical paper No. 169. 
Maasdorp, G. (1998), "Regional trade and food security in SADC", Food Policy, 23, 505-18.

Meade, J.E. (1955), “The Theory of Customs Union”, Amsterdam: North Holland

Nyirabu, M. (2004), “Appraising regional integration in southern Africa”, African Security Review 13, 21-32.

Panagariya, A. (1999), "The regionalism debate: An overview", The World Economy 22, 477-512.

(2000), "Preferential trade liberalization: The traditional theory and new developments", Journal of Economic Literature XXXVIII, 287-331.

Radelet, S. (1997), "Regional integration and cooperation in sub-Saharan Africa: Are formal trade agreements the right strategy?", Harvard Institute for International Development, Harvard University, Cambridge, Development Discussion Paper No. 592.

Subramanian A., Tamirisa, N. (2003), "Is Africa Integrated in the Global Economy?", IMF Staff Papers, 50, 352-72.

UN Comtrade (2011), “United Nations Commodity Trade Statistics Database”, [WWW page]. URL < http://comtrade.un.org/db> Accessed January 2011.

Vaillant, M., Ons, A. (2003), "Winners and losers in a free trade area between the United States and Mercosur", Working Paper No. 14/03, Departamento de Economía, Universidad de la República, Montevideo. Available at http://decon.edu.uy/publica/2003/ Doc1403.pdf. As pf 27 February, 2012.

Viner, J. (1950), “The Customs Union Issue", Carnegie Endowment for International Peace, New York.

World Bank (2008), “World Development Indicators 2008”, World Bank, Washington DC.

Yeats, A.J. (1998), "What can be expected from African regional trade arrangements? Some empirical evidence", Policy research working paper 2004, Development Research Group, World Bank, Washington, DC. 


\section{Appendices}

\section{Appendix 1: Indexes of Revealed Comparative Advantage and Disadvantage}

Revealed Comparative Advantage (RCA) index for commodity $i$ in country $k$ is defined as the ratio of the share of this commodity in total exports from $k\left(x_{i}^{k}\right)$ to the share of exports of $i$ in total exports of a reference group of countries $\left(x_{i}^{R}\right)$ :

$$
R C A_{i k}=x_{i}^{k} / x_{i}^{R}
$$

Similarly, Revealed Comparative Disadvantage (RCD) index for commodity $i$ in country $k$ is the ratio of the share of $k$ 's imports of this commodity in total imports of $k$ $\left(m_{i}{ }^{k}\right)$ to the share of imports of $i$ in total imports of a reference group of countries $\left(m_{i}{ }^{R}\right)$ :

$$
R C D_{i k}=m_{i}^{k} / m_{i}^{R}
$$

\section{Appendix 2: Trade Complementarity}

Formally, the set of industries showing Trade Complementarity in Southern African Development Community (SADC) is defined as follows,

$$
T C I^{A B}=\left\{i / R C A_{i}^{B}>1 \text { and } R C A_{i}^{A}>1\right\} \text { with } A \neq B
$$

where $i$ represents a particular industry, and $A$ and $B$ are importing and exporting SADC countries, respectively. Industry $i$ shows complementarity if one or more countries $B$ in the region have a RCA in that industry and at least one country $A$ shows a RCD.

\section{Appendix 3: Sensitive Industries}

The group of Sensitive Industries (SI) is a subset of the set of industries showing Trade Complementarity (TCI). Industries are not sensitive if the exporting country faces a 
zero tariff before the RTA comes into force,

$$
S I^{A B}=\left\{i \in T C I / X_{i}^{B}>0, \text { and } M_{i}^{A}>0 \text {, and } t_{i}^{A B}>0\right\} \text { with } A \neq B
$$

In words, these are industries $i$ that belong to TCI for which there is at least one exporter $B$ and at least one importer $A$ in the region, and for which $B$ 's exports to $A$ faced a positive tariff before the RTA.

We use ad valorem equivalent measures of tariff duties and tariff rate quotas at the six-digit level of the harmonized system (5,111 products) from Bouët et al. (2004) to determine industries in SADC countries protected by tariffs.

\section{Appendix 4: Protection Regimes}

The sensitive products turn into trade perils for $A$ when there is a displacement of domestic production in $A$ led by imports from country $B$. The perils set of industries for $A$ resulting from $B$ 's exports is,

$$
P E^{A B}=\left\{i \in S I \text { and } Y_{i}^{A-R T A}<Y_{i}^{A}\right\}
$$

As a consequence of the RTA, domestic production ( $Y$ ) of $i$ in country $A$ is displaced by imports: the industry in country $A$ (importer) is threatened by the RTA.

The sensitive products turn into trade opportunities for country $B$ when as a result of the RTA, there is an expansion of its production driven by exports to country $A$. The set of industries offering opportunities to exporter $B$ is then defined as follows,

$$
O P^{B A}=\left\{i \in S I \text { and } X_{i}^{B-F T A}>X_{i}^{B}\right\}
$$

Protection regimes are defined following Vaillant and Ons (2003) based in these two definitions.

For a particular product, the enhanced protection case implies an opportunity but not a peril: 


$$
E N^{A B}=\left\{i \in O P^{B A} \text { and } i \in P E^{A B}\right\}
$$

The reduced protection case implies a peril but not an opportunity:

$$
P P^{A B}=\left\{i \in O P^{B A} \text { and } i \in P E^{A B}\right\}
$$

The intermediate case implies an opportunity and a peril:

$$
I N^{A B}=\left\{i \in O P^{B A} \text { and } i \in P E^{A B}\right\}
$$

\section{Appendix 5: Trade Regimes}

Given the previous definitions, industries expected to face reduced protection in importing SADC markets $A$ are those for which import demand at exporter's prices is smaller than exporter's supply at the same prices

$$
1>\frac{P_{i}^{B} m_{i}^{A}\left(P_{i}^{B}\right)}{P_{i}^{B} X_{i}^{B}\left(P_{i}^{B}\right)}
$$

Industries expected to face increased protection as a result of regional trade liberalization are those for which import demand at importer's prices is greater than the value of exporter's supply at importer's prices

$$
1<\frac{P_{i}^{A} m_{i}^{A}\left(P_{i}^{A}\right)}{P_{i}^{A} X_{i}^{B}\left(P_{i}^{A}\right)}
$$

Finally, intermediate industries are those for which import demand at exporter's prices is smaller than exporter's supply at the same prices and at the same, import demand at 
importer's prices is greater than the value of exporter's supply at importer's prices

$$
1>\frac{P_{i}^{B} m_{i}^{A}\left(P_{i}^{B}\right)}{P_{i}^{B} X_{i}^{B}\left(P_{i}^{B}\right)} \text { and } 1<\frac{P_{i}^{A} m_{i}^{A}\left(P_{i}^{A}\right)}{P_{i}^{A} X_{i}^{B}\left(P_{i}^{A}\right)}
$$

Because of the limited information on supply and supply elasticities of industries at this level of disaggregation, we were able to classify sensitive industries into two groups: those industries facing reduced protection and all other industries (enhanced protection and intermediate). We did this by estimating the ratio between import demand of a particular industry $i$ in SADC importing markets $A$ and the aggregate value of supply in the group of SADC countries exporting products from that industry $B$, both at the exporter's prices. As in Vaillant and Ons (2003), the value of import demand at the exporter's prices is calculated using observed values as follows,

$$
P_{i}^{B} m_{i}^{A}\left(P_{i}^{B}\right)=\frac{P_{i}^{A} m_{i}^{A}\left(P_{i}^{A}\right)}{\theta^{A B}}\left(1+\left(\frac{1}{\theta^{A B}}-1\right) \varepsilon_{i}^{A}\right)
$$

where $\theta^{A B}=P^{A}{ }_{i} / P^{B}{ }_{i}$ is a measure of relative efficiency between the importer $A$ and the exporter $B$ and $\varepsilon_{i}^{A}$ is the import elasticity in $A$ derived from a simple calculation using import demand elasticity:

$$
P_{i}^{B} m_{i}^{A}\left(P_{i}^{B}\right)=P_{i}^{A} m_{i}^{A}\left(P_{i}^{A}\right) \times\left[\left(P_{i}^{A}-P_{i}^{B}\right) / P_{i}^{A}\right] \times \varepsilon_{i}^{A}
$$

For those industries for which the value of import demand at exporter's prices was smaller than exports from the region, there was no need to determine supply in exporting countries. For those cases in which the value of imports was bigger than exports, we used supply data from different sources, depending on the industry. For basic agricultural products, information was collected from the FAOSTAT (Food and Agriculture Organization [FAO] 2008) database. For processed manufactured products, we used production data from similar industries from the Global Trade Analysis Project 
(GTAP) database (Dimaranan 2006). Because of the lack of information on production for some industries, we relied on information from the production of similar industries as a proxy for the missing values.

To check how this constraint might have affected the allocation of sensitive industries among industries with reduced protection and among other industries, we estimated the ratio of import demand at export prices and supply at current prices, using exports as a proxy for supply. Allocating industries using exports as a proxy for supply results in 52 of the 85 sensitive industries showing an import/export ratio less than 1 (61 percent of all sensitive industries). Of the 33 industries with import/export ratio greater than one, 16 industries have ratios greater than 2 and tariffs greater than 10 per cent. For only 13 of these industries, we used data from similar or more aggregated industries to estimate supply. We conclude that inaccuracies in supply estimates due to the lack of data should not have a significant effect on our results.

\section{Appendix 6: Import Elasticities}

Table A1 show estimates of import elasticities by Broda, Greenfield, and Weinstein (2006). We present elasticities available for three Southern African countries and averages for High-Income (HI), Developing (DV), and Poor (PR) countries. One pattern that can be observed in the table is the lower elasticity of imports in more developed countries. There is also great variability within the different groups of countries. Elasticities for Madagascar and Malawi, which are among the poorest countries in the sample, are higher than those in the group of PR countries, whereas elasticities in Mauritius are larger than those in HI countries but lower than the average of DV countries. There is also variability among elasticities of different groups of industries within the groups of countries. This variability demonstrates the importance of having country-specific estimates. For instance, the import elasticity of beverages, tobacco, and cereals is relatively high in the three groups of countries (HI, DV, and PR) and in Mauritius, but it is low in Madagascar and Malawi. On the other hand, elasticities for food preparations are higher in Madagascar and Malawi than in the groups of DV and PR countries. In the case of import elasticities for fruits and vegetables, Madagascar and Malawi show relatively high elasticities, as is the case in the groups of DV and PR countries.

Because we do not have elasticity estimates for all SADC countries and because of 
the variations we observed among the elasticities in average groups of countries and elasticity values in Madagascar, Malawi, and Mauritius, we assume that elasticities for other Southern African countries are more likely to be closer in value to those estimated for countries in the region. We try to capture what appear to be robust differences between elasticity values of countries with different levels of income by using values for Malawi and Mozambique for low-income countries in the region, while we used Mauritius's elasticities for Southern African middle-income countries.

Table A1. Import Elasticities

\begin{tabular}{|c|c|c|c|c|c|c|c|}
\hline HS & Description & $\begin{array}{l}\text { High } \\
\text { Income }\end{array}$ & Developing & Poor & Madagascar & Malawi & Mauritius \\
\hline 010 & Live animals & 11.43 & 31.61 & 10.78 & 3.39 & & 33.55 \\
\hline 020 & Meat & 10.79 & 12.4 & 19.97 & & 6.02 & 2.65 \\
\hline 030 & Fish & 5.39 & 17 & 22.61 & & & 3.52 \\
\hline 040 & Dairy \& eggs & 6.31 & 10.21 & 12.35 & 17.74 & 103.03 & 7.76 \\
\hline 041 & Other edible animal products & 2.44 & 47.12 & 3.74 & & & 0 \\
\hline 050 & Products of animal origin & 3.84 & 10 & 13.51 & & & 6.62 \\
\hline 051 & Other indedible animal products & 5.67 & 11.416 & 12.73 & & & 0 \\
\hline 060 & Live gtrees \& plants & 3.49 & 8.83 & 2.85 & & & 6.7 \\
\hline 070 & Vegetables fresh or frozen & 3.74 & 10.97 & 20.18 & & & 1.78 \\
\hline 071 & Vegetables Preserved & 4.34 & 12.16 & 32.89 & 33.55 & & 5.8 \\
\hline 080 & Fruits fresh & 4.54 & 19.27 & 21.99 & 103.03 & 103.03 & 5.79 \\
\hline 081 & Fruits preserved & 3.89 & 10.93 & 9.02 & & & 3.07 \\
\hline 090 & Coffee, tea \& spices & 6.21 & 10.21 & 7.29 & 76.89 & & 5.11 \\
\hline 091 & Other spices & 4.8 & 20.61 & 38.47 & & & 3.14 \\
\hline 100 & Cereals & 4.3 & 10.96 & 17.33 & 4.45 & 2.19 & 8.17 \\
\hline 110 & Milling industry products & 4.29 & 5.96 & 7.68 & 3.24 & 3.96 & 15.23 \\
\hline 120 & Oilseeds & 6.39 & 9.8 & 19.27 & 6.7 & 2.35 & 2.58 \\
\hline 121 & Miscelaneous grains \& plants & 5.24 & 9.45 & 20.96 & 0 & & 1.61 \\
\hline 130 & Natural gums, resins, etc. & 6.57 & 9.97 & 23.71 & 3.71 & & 2.79 \\
\hline 140 & Vegetable plant materials & 6.09 & 19.02 & 44.71 & & & 0 \\
\hline 150 & Animal fats \& vegetable oils & 4.2 & 8.56 & 4.54 & 6.95 & 6.61 & 4.03 \\
\hline
\end{tabular}




\section{Table A1. Import Elasticities}

(Continued)

\begin{tabular}{|c|c|c|c|c|c|c|c|}
\hline HS & Description & $\begin{array}{c}\text { High } \\
\text { Income }\end{array}$ & Developing & Poor & $\begin{array}{c}\text { Madagas- } \\
\text { car }\end{array}$ & Malawi & Mauritius \\
\hline 151 & Other vegetable oils & 4 & 15.65 & 16.9 & 3.16 & 125.24 & 6.72 \\
\hline 152 & Waxes \& oil residues & 5.93 & 9.7 & 22.74 & & & 1.75 \\
\hline 160 & Edible preparations of meat and fish & 5.93 & 7.34 & 14.43 & 2.65 & 2.79 & 8.58 \\
\hline 170 & Sugar \& sugar confectionary & 5.4 & 9.11 & 7 & 2.93 & 1.48 & 2.41 \\
\hline 180 & Cocoa \& cocoa preparations & 7.37 & 12.5 & 12.67 & 73.22 & & 5.75 \\
\hline 190 & Preparations of cereals, flour, starch or milk & 4.64 & 13.5 & 8.92 & 6.28 & 3.7 & 4.04 \\
\hline 200 & Preparations of vegetables, fruits \& nuts & 6.01 & 9.74 & 11.03 & 5.04 & 119.28 & 6.45 \\
\hline 210 & Miscelaneous edible preparations & 4.89 & 11.16 & 11.5 & 93.46 & 9.44 & 5.04 \\
\hline 220 & Beverages & 6.29 & 6.9 & 3.19 & 3.08 & 1.67 & 1.74 \\
\hline 230 & Animal feed & 4.97 & 34.61 & 7.66 & 25.03 & 4.09 & 5.19 \\
\hline \multirow[t]{2}{*}{240} & Tobacco manufacture of tobacco & 11.27 & 26.47 & 28.2 & 2 & 4.45 & 33.55 \\
\hline & Main product groups & & & & & & \\
\hline 010-051 & Livestock \& meat & 6.56 & 14.26 & 13.67 & 10.56 & 54.53 & 7.73 \\
\hline 070-081 & Fruits \& vegetables & 4.13 & 13.33 & 21.02 & 68.29 & 103.03 & 4.11 \\
\hline $100-110$ & Cereals \& milling products & 4.29 & 8.46 & 12.5 & 3.84 & 3.07 & 11.7 \\
\hline $\begin{array}{l}060, \\
090-091, \\
120-140\end{array}$ & Other crops & 5.54 & 12.55 & 22.47 & 21.83 & 2.35 & 3.13 \\
\hline $150-152$ & Oils \& fats & 4.71 & 11.3 & 14.73 & 5.06 & 65.93 & 4.17 \\
\hline $160-210$ & Food preparations & 5.71 & 10.56 & 10.92 & 30.6 & 27.33 & 5.38 \\
\hline 220,240 & Beverages \& tobacco & 8.78 & 16.68 & 15.7 & 2.54 & 3.06 & 17.64 \\
\hline & Average & 5.65 & 13.22 & 15.96 & 22.69 & 31.21 & 6.28 \\
\hline
\end{tabular}

(Notes) (i) HS=Harmonized System

(ii) High Income includes Australia, Austria, Canada, Cyprus, Denmark, Finland, France, Germany, Greece, Hong Kong, Iceland, Ireland, Italy, Japan, Korea, Netherlands, New Zealand, Norway, Portugal, Spain, Sweden, Switzerland, United Kingdom and United States.

(iii) Developing includes Algeria, Argentina, Brazil, Chile, Colombia, Ecuador, Egypt, El Salvador, Gabon, Jordan, Mexico, Morocco, Peru, Thailand, Tunisia, Turkey, Uruguay and Venezuela.

(iv) Poor countries includes Bolivia, Central African Rep, Guatemala, Honduras, Indonesia, Nicaragua, Sri Lanka, and Togo.

(Source) Based on Broda, Greenfield, and Weinstein (2006). Elasticities available at http://faculty.chicagobooth. edu/christian.broda/website/research/unrestricted/TradeElasticities/TradeElasticities.html 
In Table A2, we calculate welfare results for Mozambique using three different import elasticities to check the possible effect of the choice of elasticities in our results. The base elasticities are those used in the study. The other two results are obtained using the elasticities of the Developing and the Poor groups, respectively, presented in Table A1. The use of different elasticities does not change the results. In every case, Mozambique experienced a welfare loss. The results appear to be consistent for the different industries, as in most cases (especially for the most important industries) results with different elasticities show the same sign. 


\section{Table A2. Welfare Gains by Mozambique after the Elimination of Tariffs between SADC Countries Using Different Import Elasticities}

\begin{tabular}{|c|c|c|c|c|}
\hline SITC & Description & $\begin{array}{c}\text { Base } \\
\text { elasticity }\end{array}$ & $\begin{array}{c}\text { Elasticity } \\
\text { poor }\end{array}$ & $\begin{array}{r}\text { Elasticity } \\
\text { developed }\end{array}$ \\
\hline 0013 & Swine & 1 & 5 & 16 \\
\hline 0422 & Rice, glazed polished, not further prepared & -1943 & -1657 & -1787 \\
\hline 0459 & Cereals, unmilled,nes & -3 & 72 & 38 \\
\hline 0460 & Meal and flour of wheat or of meslin & 209 & 569 & 417 \\
\hline 0481 & Cereal grains, flaked, pearled & -250 & -245 & -247 \\
\hline 0482 & Malt including malt flour & 0 & 1 & 0 \\
\hline 0484 & Bakery products & -452 & -443 & -432 \\
\hline 0542 & Beans, peas, lentils leguminous vegetables, dried & -73 & 488 & 207 \\
\hline 0544 & Tomatoes, fresh & -38 & -15 & -26 \\
\hline 0545 & Other fresh vegetables & -100 & 60 & -20 \\
\hline 0548 & Vegetable products, chiefly for human food nes & -8 & 2 & -3 \\
\hline 0611 & Raw sugar, beet and cane & -588 & -531 & -505 \\
\hline 0752 & Spices excluding Pepper \& pimento ground or not & -99 & -105 & -95 \\
\hline 0814 & Meat \& fish meal unfit for human consumption & 8 & 13 & 6 \\
\hline 0914 & Margarine imitn lard \& prepared edible fats nes & 47 & -67 & 4 \\
\hline 1121 & Wine of fresh grapes including grape must & -1093 & -1093 & -1093 \\
\hline 1123 & Beer including ale, stout, porter & -69 & 12 & 377 \\
\hline 1223 & Tobacco manufactured for smoking chewing snuff & 28 & 385 & 360 \\
\hline 2440 & Cork raw \& waste & 0 & 1 & 0 \\
\hline 2711 & Natural fertilizers of animal/vegetable Origin & 0 & 1 & 1 \\
\hline 2925 & Seeds fruit \& spores for planting & -6 & -6 & -6 \\
\hline 4113 & Animal oils, fats and greases excluding lards & 0 & -3 & 2 \\
\hline \multirow[t]{2}{*}{6511} & Thrown silk \& silk yarn and thread & 0 & 1 & 0 \\
\hline & Total & -4429 & -2555 & -2786 \\
\hline
\end{tabular}

(Note) SITC $=$ Standard Internation Trade Classification

(Source) Author's calculations based on UN Comtrade data 